\title{
Dynamics of $\alpha$-D-mannose carbohydrate-binding sites distribution in rats' pancreatic structures during the morpho-functional formation
}

\author{
N. V. Hrinivetska, Yu. O. Burega, I. M. Maslova \\ Zaporizhzhia State Medical University, Ukraine
}

Key words: pancreas, rats, antigen, carbohydrates, mannose.

\section{Zaporozhye}

medical journal

2017; 19 (6), 764-768

DOI:

10.14739/2310-1210

2017.6.114718

E-mail:

nataliagrin7@gmail.com
Recently, the pathology of pancreas in children is observed more frequently. Precursors of inflammation development in pancreas are dysfunctional disorders, which include conditions accompanied by changes in pancreatic secretion in the absence of morphological abnormalities. The pancreas is especially sensitive to irritants in the antenatal period of development and during its morpho-functional formation. Placental function insufficiency and prenatal effects of various pathogens on the fetus can cause abnormalities of morphogenesis. The above determines the relevance of the study, which allows ascertaining the features of the fetus pancreas formation in conditions of antigenic nature substances action.

The aim - to study the dynamics of $\alpha$-D-Mannose carbohydrate-binding sites distribution in rats' pancreatic structures during the morpho-functional formation, using lectin histochemistry analysis.

Materials and methods. Research was conducted on pancreases of white laboratory rats from the day of birth to ninety days of postnatal development. The experimental group of rats was injected intrafetal with an antigenic solution subcutaneously in the interscapular region. Detection of carbohydrate residues of $\alpha$-D-Mannose was carried out by lens culinaris agglutinin (LCA), which conjugated with horseradish peroxidase.

Results. Antigenic action in the antenatal period results to decrease in density of $\alpha$-D-Mannose residues in pancreatic structures from the first to the third day of postnatal life. From the seventh day and until the fourteenth day the density of LCA receptors in experimental group has increased. From the twenty first until ninetieth days of life the distribution of carbohydrate receptors to LCA in the experimental group was not differ from the control and intact group.

Conclusions. The increase in density of carbohydrate residues of $\alpha$-D-Mannose in pancreatic structures in early postnatal period is the sign of immaturity, which may have the direct effect on secretory activity of organ.

\section{Кмючові слова:} піАшлункова залоза, щури, антиген, вуглеводи, маноза.

Запорізький медичний

журнал. - 2017. -

T. 19, № 6(105). -

C. 764-768

\section{Аинаміка розподілу вуглеводних детермінант $\alpha$-D-манози у структурах підшлункової залози щурів у період ії морфофункціонального становлення}

\section{Н. В. Грінівецька, Ю. О. Бурега, І. М. Маслова}

Останнім часом частіше виявляється патологія підшлункової залози у дітей. Розвитку запальних процесів у підшлунковій залозі у дітей передують дисфункціональні розлади, що супроводжуються змінами секреції, за відсутності морфологічних відхилень. Підшлункова залоза особливо чутлива до подразників у період антенатального розвитку та в період її морфоффункціонального становлення. Порушення функції плаценти та внутрішньоутробна дія на плід збудників різної природи, особливо вірусної, можуть бути причиною відхилень морфогенезу органів після народження. Вищевикладене визначає актуальність дослідження, що дає можливість встановити особливості формування підшлункової залози новонароджених за умов дії на плід речовин антигенної природи.

Мета роботи - встановити динаміку розподілу вуглеводних детермінант a-D-манози у структурах підшлункової залози щурів у період морфофункціонального становлення з 1 до 90 доби після народження.

Матеріали та методи. Дослідження здійснили на підшлункових залозах білих лабораторних щурів від моменту народження до дев'яностої доби постнатального розвитку. Експериментальній групі щурів на 18 добу антенатального розвитку внутрішньоплідно підшкірно в міжлопаткову ділянку введено розчин антигена. Виявлення вуглеводних залишків a-D-манози проводили за допомогою лектингістохімічної реакції із застосуванням лектину сочевиці (LCA), що кон'югований із пероксидазою хрону.

Результати. Антигенна дія в антенатальному періоді призводить до зменшення кількості залишків $\alpha$-D-манози у структурах підшлункової залози з першої до третьої доби життя. 3 сьомої по чотирнадцяту добу спостереження кількість рецепторів до лектину сочевиці в експериментальних групах тварин збільшена. 3 двадцять першої по дев'яносту добу життя кількість рецепторів до лектину сочевиці в експериментальних групах не відрізняється від інтактної та контрольної груп.

Висновки. Зниження в ранньому післянатальному періоді щільності вуглеводних залишків $\alpha$-D-манози у структурах підшлункової залози є ознакою їхньої незрілості, що може надалі мати безпосередній вплив на секреторну активність органа.

\section{Аинамика распределения углеводных детерминант $\alpha$-D-маннозы в структурах поджелудочной железы крыс в период морфофункционального развития}

\section{Н. В. Гринивецкая, Ю. А. Бурега, И. Н. Маслова}

Наряду с заболеваемостью взрослых, в последнее время чаще отмечается патология поджелудочной железы у детей. Развитию воспалительных процессов в поджелудочной железе у детей предшествуют дисфуннциональные расстройства, к которым относятся состояния, сопровождающиеся изменениями панкреатической секреции, при отсутствии морфологических отклонений. Поджелудочная железа, имея высокую уязвимость к действию различных факторов, особенно чувствительна к раздражителям в период морфофункционального становления. Нарушение функции плаценты 
и внутриутробное действие на плод возбудителей различной природы могут быть причиной отклонений морфогенеза органов. Вышеизложенное определяет актуальность исследования, что позволит установить особенности формирования поджелудочной железы в условиях воздействия на плод веществ антигенной природы.

Цель работы -установить динамику распределения углеводных детерминант a-D-маннозы в структурах поджелудочной железы крыс в период морфофункционального становления с помощью лектингистохимического анализа.

Материалы и методы. Исследования проводились на поджелудочных железах белых лабораторных крыс от момента рождения до девяностых суток постнатального развития. Экспериментальной группе крыс на 18 сутки антенатального развития внутриутробно подкожно в межлопаточную область вводился раствор антигена. Выявление углеводных остатков а D-маннозы проводили с помощью лектингистохимической реакции с применением лектина чечевицы (LCA), обработанной пероксидазой хрена.

Результаты. Интенсивность отложения бензидиновой метки оценивали полуколичественно. Антигенное действие в антенатальном периоде приводит к уменьшению количества остатков a-D-маннозы в структурах поджелудочной железы c первых по третьи сутки жизни. С седьмых по четырнадцатые сутки наблюдения количество рецепторов к лектину чечевицы в экспериментальных группах животных увеличено. С двадцать первых по девяностые сутки жизни количество рецепторов к лектину чечевицы в экспериментальных группах не отличалось от таковых в интактной и контрольной группах.

Выводы. Увеличение в раннем постнатальном периоде плотности углеводных остатков a-D-маннозы в структурах поджелудочной железы является признаком их незрелости, что может иметь непосредственное влияние в дальнейшем на секреторную активность органа.

\section{Background}

Recently, pancreas pathologies are more frequently observed in children. Prior to the inflammation development in the pancreas in children come dysfunctional disorders involving changes in pancreatic secretion if any morphological abnormalities are absent $[6,8]$. The admission of reduced number of pancreatic enzymes to the gastrointestinal tract does not provide a full breakdown of proteins, fats and carbohydrates, which then may affect different types of exchange disorders, especially for infants. Maldihestiya can cause malnutrition in infants, various vitamin deficiencies, abdominal pain syndrome and subsequently lead to the development of food allergies in children during the first three years of life $[1,5]$. Pancreas is characterize by a high vulnerability to the action of various factors and is particularly sensitive to stimuli during morpho-functional formation in post-natal period $[2,10]$. Development of pancreas structures in physiological pregnancy is studied deeply [8]. But, in our country as well as abroad, the frequency of abnormal pregnancy and pregnant women infected by various bacterial and viral agents remains high [3,7]. Impaired function of the placenta leads to effects on the fetus with pathogens of different nature (virus, antigenic, toxic), which can cause abnormalities of morphogenesis. Due to the frequent epidemics of influenza in recent years, it is prevented with vaccination of pregnant women. Since numerous diseases of children and adults are associated with the rejection of fetal development after exposure to antigens [2,8], expansion of anatomical studies of the pancreas in the perinatal period of development is an urgent morphological task $[4,6,9]$.

\section{The aim}

The aim - to study the dynamics of a-D-Mannose carbohydrate-binding sites distribution in rats' pancreatic structures during the morpho-functional formation, using lectin histochemistry analysis.

\section{Materials and methods}

Research was conducted on 168 pancreases of white laboratory rats from the moment of birth to the ninetieth day of postnatal life. Rats were divided into three groups. The $1^{\text {st }}$ group was the intact rats. The $2^{\text {nd }}$ group consisted from rats, which were injected with $0.05 \mathrm{ml}$ solution of antigen in the amniotic fluid on the $18^{\text {th }}$ day of fetus formation by the method of N. Voloshyn; the $3^{\text {rd }}$ group - control, the animals were injected intrafetal with $0.05 \mathrm{ml}$ of $0.9 \%$ sodium chloride solution on the $18^{\text {th }}$ day of fetus formation. For the study of pancreatic structures morphogenesis features after antigen's action on the fetus the model of transuterine, transmembrane intrafetal subcutaneously substances administration in the interscapular region by the method of $\mathrm{N}$. Voloshyn was chosen. The antigen was liquid (killed) split - vaccine Vaxigrip 2009. Keeping the animals and experiments were carried out according to regulations of European Convention about the defence of spine animals', which are used due to the experimental and other scientific aims (Strasbourg, 2005), low of Ukraine "Animal Protection from Cruel Appeal" (No 1759 from 15.09.2009). The animals' killing and taking of the material were done on the $1^{\text {st }}, 3^{\text {rd }}, 7^{\text {th }}$, $14^{\text {th }}, 21^{\text {st }}, 45^{\text {th }}$ and $90^{\text {th }}$ days of postnatal life.

Determination of the carbohydrates residues of $\alpha-D$ manose (Man) was conducted using lectin histochemical reaction with lens culinaris agglutinin (LCA), which conjugated with horseradish peroxidase through the standard lectins kits NVK "Lectintest" (Lviv). Visualization of lectins binding - zones was implemented in the system diaminobenzidine-hydrogen peroxide. Evaluation of the results and photo-documentation was conducted using the microscope Axioplan 2 (Carl Zeiss, Germany) and digital camera C5060WZ (Olympus, Japan). For the findings' unification the photographing was conducted in the standard conditions: the magnification $\times 200$, the color (temperature) of light 3200 $\mathrm{K}$; the parameters of photo camera F3.2 (diaphragm), 1/400 (delay), ISO 100 (photosensitivity), manual balance of white "in one touch". Quantitative determination the intensity of benzidine label levels in the pancreatic structures was done using the program for processing of digital images "ImageJ" with built-in plug-in Color Deconvolution. The results were evaluated as conventional optical coefficient (c.o.c.) of digital image pixels number of hyperchromic structures general area to the background staining ratio.

The quantitative results of the study were estimated using the statistical package Statistica ${ }^{\circledR}$ for Windows 6.1 
(StatSoft Inc., № AXXR712D833214FAN5 license). For the statistical significance of variables evaluation non-parametric Mann-Whitney $U$ test was used. The results were considered significant at $P<0.05$. The correlative analysis was conducted with Spearman's criterion. The correlation coefficient was considered significant at $P<0.05$. The data in the table are presented as arithmetic mean value, where " \pm " is the standard error of means.

\section{Results and discussion}

During experiment the indicators of intact group had not significant difference from the control group that is why these terms will be used as synonyms in the text. In control newborn rats the pancreatic capsule and its connective tissue stained brown, that corresponded $2.36 \pm 0.21$ c.o.c. Epithelial cells of ductal and vascular components didn't have differences in density of receptors to lens culinaris agglutinin and stained in intermediate colors in the range from the brown to light brown ( $2.57 \pm 0.21$ c.o.c.). In parenchymal cells the expression of carbohydrates determinants to lens agglutinin was at the minimum level. In experimental group of animals, which were administrated of antigen in the antenatal period, increase in density of $\alpha$-D-Mannose residues in the organs' structures was detected. In the pancreatic capsule and connective tissue the conventional optical coefficient was $2.57 \pm 0.11$ and $2.61 \pm 0.24$ respectively. The vascular and ductal walls were staining from the light brown to brown, that had an equivalent as conventional optical coefficient with statistically significant difference $(P<0.05): 1.58 \pm 0.17$ and $1.61 \pm 0.21$ in comparison with the intact group.

The pancreatic acinar cells were characterized by the lower affinity to lens agglutinin in comparison with the control group.
Seventy-two hours later after birth in animals of intact group the content level of carbohydrate component of a-D-Mannose in the connective tissue and in the walls of vascular and ductal apparatus had the same expressional level as on the $1^{\text {st }}$ day of life. The ultrastructural receptors localization to lens agglutinin in pancreatic acinar cells also was characterized by the absence of statistically significant difference between indicators of conventional optical coefficients and coincided with the values of intact rats. In animals of the second experimental group the degree of interaction with visualization system of carbohydrate residues as well as in newborn animals, was significantly less, that it was beyond the boundaries of unreliable limit of standard error ( $2.11 \pm 0.26$ c.o.c.), in comparison with the $1^{\text {st }}$ experimental group.

By the end of the first week of observation after birth, in the control group of animals the content of agglutinin - bound a-D-Mannose in the connective tissue and epithelial layer of the vascular and ductal walls was not changed compared with the values of results, which were obtained from previous observational term animals. The cells of organs' parenchyma contained a slightly denser zone of receptors to the used agglutinin, as indicator of conventional optical coefficient was $2.58 \pm 0.32$; pancreatic connective tissue of capsule and interlobular septum had the intensive saturated staining color (3.14 \pm 0.14 and $3.09 \pm 0.13$ c.o.c. respectively $(P<0.05)$.

The stability of indicators of $\alpha$-D-Mannose carbohydrate residues' content at the end of the first week was detected on the $14^{\text {th }}$ experimental day in the control group of animals in all investigated structures. In animals which were administrated by viral antigen before birth in the organ connective tissue structures which was observed, the increased level of carbohydrate components expression to the selected agglutinin was detected, as conventional optical coefficient $(3.14 \pm 0.22)$ was contrasted with the data of control group

Table 1. Density of the receptors distribution to lens culinaris agglutinin in the pancreas from the $1^{\text {st }}$ to the $90^{\text {th }}$ days of life $(M \pm m)$

\begin{tabular}{|c|c|c|c|c|c|c|}
\hline \multirow[t]{2}{*}{ Day of life } & \multirow[t]{2}{*}{ Groups of animals } & \multicolumn{5}{|c|}{ Investigated structures } \\
\hline & & capsule & connective tissue & acinar cells & vessels wall & ducts wall \\
\hline \multirow[t]{2}{*}{1} & intact & $2.39 \pm 0.17$ & $2.41 \pm 0.11$ & $1.51 \pm 0.10$ & $2.63 \pm 0.22$ & $2.59 \pm 0.26$ \\
\hline & control & $2.36 \pm 0.14$ & $2.39 \pm 0.21$ & $1.54 \pm 0.17$ & $2.57 \pm 0.21$ & $2.57 \pm 0.17$ \\
\hline \multirow[t]{2}{*}{3} & intact & $2.11 \pm 0.18$ & $2.24 \pm 0.12$ & $1.49 \pm 0.10$ & $1.51 \pm 0.16^{\sharp}$ & $1.54 \pm 0.22^{\sharp}$ \\
\hline & experimental & $3.24 \pm 0.21^{*}$ & $3.47 \pm 0.13^{*}$ & $2.11 \pm 0.26^{*}$ & $2.76 \pm 0.13^{*}$ & $2.83 \pm 0.21^{*}$ \\
\hline \multirow[t]{3}{*}{7} & intact & $2.24 \pm 0.26$ & $2.16 \pm 0.22$ & $2.58 \pm 0.32 \#$ & $2.44 \pm 0.14$ & $2.61 \pm 0.32 \#$ \\
\hline & experimental & $3.14 \pm 0.14^{*}$ & $3.09 \pm 0.13^{*}$ & $2.31 \pm 0.17$ & $2.36 \pm 0.11$ & $2.41 \pm 0.17$ \\
\hline & control & $2.17 \pm 0.19$ & $2.24 \pm 0.13$ & $2.63 \pm 0.21$ & $2.51 \pm 0.16$ & $2.57 \pm 0.21$ \\
\hline \multirow[t]{3}{*}{14} & intact & $2.12 \pm 0.14$ & $2.31 \pm 0.26$ & $2.68 \pm 0.14$ & $2.51 \pm 0.32$ & $2.57 \pm 0.18$ \\
\hline & experimental & $3.14 \pm 0.22^{*}$ & $3.22 \pm 0.13^{*}$ & $2.38 \pm 0.21$ & $2.29 \pm 0.14$ & $2.34 \pm 0.22$ \\
\hline & control & $2.06 \pm 0.11$ & $2.26 \pm 0.18$ & $2.56 \pm 0.19$ & $2.51 \pm 0.26$ & $2.51 \pm 0.18$ \\
\hline \multirow[t]{2}{*}{21} & intact & $2.56 \pm 0.30$ & $1.51 \pm 0.10$ & $1.14 \pm 0.10$ & $2.54 \pm 0.32$ & $2.49 \pm 0.21$ \\
\hline & control & $2.51 \pm 0.16$ & $1.54 \pm 0.13$ & $1.09 \pm 0.13$ & $2.57 \pm 0.17$ & $2.51 \pm 0.17$ \\
\hline \multirow[t]{3}{*}{45} & intact & $1.39 \pm 0.06^{\sharp}$ & $1.11 \pm 0.03$ & $1.14 \pm 0.03$ & $1.39 \pm 0.06 \#$ & $1.57 \pm 0.08 \#$ \\
\hline & experimental & $1.51 \pm 0.07$ & $1.20 \pm 0.04$ & $1.17 \pm 0.04$ & $1.41 \pm 0.06$ & $1.54 \pm 0.07$ \\
\hline & control & $1.44 \pm 0.08$ & $1.14 \pm 0.03$ & $1.17 \pm 0.04$ & $1.51 \pm 0.07$ & $1.54 \pm 0.07$ \\
\hline \multirow[t]{3}{*}{90} & intact & $1.61 \pm 0.07$ & $1.18 \pm 0.06$ & $1.14 \pm 0.03$ & $1.13 \pm 0.04$ & $1.14 \pm 0.06$ \\
\hline & experimental & $1.54 \pm 0.04$ & $1.20 \pm 0.06$ & $1.12 \pm 0.04$ & $1.12 \pm 0.04$ & $1.14 \pm 0.06$ \\
\hline & control & $1.57 \pm 0.09$ & $1.16 \pm 0.04$ & $1.17 \pm 0.05$ & $1.07 \pm 0.03$ & $1.11 \pm 0.04$ \\
\hline
\end{tabular}

*: the results were considered significant compared with the intact group;

\#: the results were considered significant compared with the previous term of observation. 
$(2.12 \pm 0.14)$. Epithelial constituent of pancreas (acinar cells, vascular and ductal walls) had the density of $\alpha-D-M a n n o s e$ residues, that corresponded to the level of previous observational term ( $2.51 \pm 0.32$ c.o.c.), but in comparison with the intact rats, less expressive.

From the $21^{\text {st }}$ day of life in intact group in the pancreatic structures the level of receptors expression to lens agglutinin was decreased in organs' connective tissue to $1.51 \pm 0.10$ c.o.c. and in the acinar cells to $1.51 \pm 0.10$ c.o.c. In experimental group the content of $\alpha$-D-Mannose residues in the capsule, connective tissue and acinar cells was decreased in comparison with the previous term, but the same level was obtained in the intact group [5]. Vascular and ductal walls of organ were characterized by the moderate expression of receptors to lens agglutinin in all observational groups: $2.54 \pm 0.26$ c.o.c.

Analysis of the $45^{\text {th }}$ and $90^{\text {th }}$ days of life results showed that expression to selected agglutinin in all groups was decreased on average to the next values of conditional optical coefficient: $1.07 \pm 0.03$ in the vascular and ductal walls. The capsule, connective tissue of pancreas and cytoplasm of acinar cells in the control group by carbohydrate residues content by the level of expression were responded to previous observational term (Table 1).

Carbohydrate determinants carry much more information than proteinaceous. The carbohydrate chains - is the instrument, where more information programming is possible. The Glyco-polymeric compounds constitute the structural and functional base of cells and tissues, cells plasmatic membranes, glycocalyx, intracellular inclusions, connective tissue fibers and basic substance, and are the signal and receptor molecules, are determining the intercellular contacts, cells adhesion and migration [9]. Agglutinin-receptor interaction can initiate the agglutinin-depended mechanisms of the cell functions regulation and cells responses, that cause the differentiation of tissues and its structural components [3,9].

Our findings concerning the density and distribution of a-D-Mannose residues in the investigated structures are complementing the data of $\alpha$-D-Mannose residues distribution in the connective tissue and terminal portion of major salivary glands. With almost identical density in birth period, the changes in the receptor panel of carbohydrate determinants to lens agglutinin in the stroma of pancreas occurs before the $21^{\text {th }}$ day of postnatal formation, unlike the connective tissue structures of major salivary glands, where the same process was observed, only up to the $14^{\text {th }}$ day. This is due to first of all, the difference in the histological-genetic formation and the terms of digestive system glands final formation, despite their combining morphology-functional component. The data obtained during the research allow the concept expanding about formation and definition of pancreas in early postnatal period of ontogenesis in norm and clarify the morphogenesis of reactive changes after antigenic influence on fetus in the antenatal period.

\section{Conclusions}

The increase in density of carbohydrate residues of a-D-Mannose in pancreatic structures in early postnatal period is the sign of immatority, which may have the direct effect on secretory activity of organ.
Prospects for further research. In the further researches it is planning to determine the features and comparative analysis of membrane carbohydrate residues density distribution in the structures of the pancreatic head and body at the early postnatal stage of ontogenesis after antenatal antigenic action.

\section{References}

[1] Antonyuk, R. V., \& Lutsyk, O. D. (2015). Lektynova histokhimiia vuhlevodnykh determinant kyshky predstavnykiv riznykh klasiv khrebetnykh [Lectin histochemistry of intestinal carbohydrate determinants in representatives of different classes of vertebrates]. Morfolohiia, 9(4), 7-20. [in Ukrainian].

[2] Boiko, V. V., Akhtemiichuk, Yu. T., \& Slobodian O.M. (2008). Suchasn pohliady na poshkodzhennia pidshlunkovoi zalozy (khirurhichni aspekty) [Modern views on damage of the pancreas]. Ukrainskyi zhurnal khirurhii, 1, 87-89. [in Ukrainian].

[3] Chu, L., Zhang, J., Li, Y. N., Meng, X., \& Liu, Y. Y. (2016). Clinical treatment of infective endocarditis with vegetations in pregnant women and the outcomes of gestation. Zhonghua Fu Chan Ke Za Zhi., 51(5), 331-8. doi: 10.3760/cma.j.issn.0529-567X.2016.05.003.

[4] Dovgal,' G. V., Dovgal,' M. A., Supon'ko, Yu. V., \& Voloshin, N. A. (2016) Gistokhimicheskaya dinamika glikozaminoglikanov v podzheludochnoj zheleze krys pri estestvennom izmenenii tipa pitaniya v postnatal'nom periode [Histochemical dynamics of glycosaminoglycans in the pancreas of rats with the natural change of the type of power in the postnatal period]. Visnyk problem biolohi ta medytsyny, 2(129), 27-29. [in Ukrainian].

[5] Koctiuk, H. Ya. (2014). Naslidky pidvyshchenoho tysku u prototsi pidshlunkovoi zalozy [Consequences of increased pressure in the pancreatic duct]. Visnyk Vinnytskoho natsionalnoho medychnoho universytetu, 1(18), 30-32. [in Ukrainian].

[6] Maslova, I. N. (2014). Glyconjugates distribution features in the rat's major salivary glands structures after antenatal antigen action. Ukrainian scientific medical youth jornal. 4(83), 135-136.

[7] Oz, H. S., \& Tobin, T. (2012). Atovaquone ameliorate gastrointestinal toxoplasmosis complications in a pregnancy model. Med Sci. Monit., 18(9), BR337-345. doi: 10.12659/MSM.883342.

[8] Slobodian, O. M. (2013). Histotopohrafichni osoblyvosti pankreatoduodenalnoho orhanokompleksu u plodiv ta novonarodzhenykh [Histotopographic features of the pancreatoduodenal organo - complex in fetus and newborns]. Morfolohiia, 2(4), 47-50. [in Ukrainian].

[9] Voloshin, N. A., \& Grigor'eva, E. A. (2005). Lektiny zhivotnogo i rastitel'nogo proiskhozhdeniya: rol' v processakh morfoheneza [Lectins of animal and vegetable origin: a role in morphogenesis processes]. Zhurnal Akademii medicinkikh nauk Ukrainy, 11(2), 223-227. [in Russian].

[10] Voloshin, N. A., Grigor'eva, E. A., \& Dovbysh, M. A. (2004). Ispol'zovanie metodov lektinovoj gistologii $v$ citologii [The use of the lectin in histology and cytology]. Tavricheskij mediko-biologicheskij vestnik, 7(4), 40-41. [in Russian].

\section{Information about authors:}

Hrinivetska N. V., MD, PhD, Assistant,

Department of Human Anatomy, Operative Surgery and Topographic Anatomy, Zaporizhzhia State Medical University, Ukraine.

Burega Yu. O., MD, PhD, Associate Professor, Department of Propedeutics and Surgical Dentistry, Zaporizhzhia State Medical University, Ukraine.

Maslova I. M., MD, PhD, Assistant, Department of Propedeutics and Surgical Dentistry, Zaporizhzhia State Medical University, Ukraine.

\section{Відомості про авторів:}

Грінівецька Н. В., канд. меА. наук, асистент каф. анатомії мюдини, оперативної хірургії та топографічної анатомії, Запорізький Аержавний медичний університет, Україна.

Бурега Ю. О., канА. меА. наук, Аоцент каф. пропедевтичної та хірургічної стоматології, Запорізький Аержавний медичний університет, Україна.

Маслова І. М., канА. меА. наук, асистент каф. пропедевтичної та хірургічної стоматології, Запорізький Аержавний медичний університет, Україна. 


\section{Сведения об авторах:}

Гринивецкая Н. В., канА. мед. наук, ассистент каф. анатомии

человека, оперативной хирургии и топографической анатомии,

Запорожский государственный меАицинский университет,

Украина.

Бурега Ю. А., канА. меА. наук, Аоцент каф. пропедевтической

и хирургической стоматологии, Запорожский государственный

медицинский университет, Украина.

Маслова И. Н., канА. меА. наук, ассистент

каф. пропедевтической и хирургической стоматологии,

Запорожский государственный меАицинский университет,

Украина.

Конфлікт інтересів: віАсутній.

Conflicts of Interest: authors have no conflict of interest to declare.

Надійшло Ао реАакції / Received: 01.06.2017

Після Аоопрацювання / Revised: 16.06.2017

Прийнято Ао Аруку / Accepted: 11.07.2017 